\title{
SURVEY OF INTERNATIONAL LAW LITERATURE PUBLISHED IN 2004 WITH SPECIAL RELEVANCE TO ASIA
}

\author{
Compiled and Edited by Bimal N. Patel"
}

\section{Areas of international law:}

Air and space

Arbitration

Arms control and disarmament

Conflicts and disputes

Criminal law, humanitarian law and terrorism

Economic relations, trade and finance

Environment, natural resources and sustainable development

General

International courts and tribunals
Individuals, groups of persons - human rights

Legal education

National and international law

Peace-keeping, peace-making and

peace-building

States and groups of states

United Nations and other international/ regional organizations and regional laws

\section{Abbreviations:}

AJIL American Journal of International Law

Arizona JICL Arizona Journal of International and Comparative Law

Brooklyn JIL Brooklyn Journal of International Law

CJIL Chinese Journal of International Law

CLP China Law and Practice

Fordham ILJ Fordham International Law Journal

HKLJ Hong Kong Law Journal

ICLQ International and Comparative Law Quarterly

IJIL Indian Journal of International Law

JALC Journal of Air Law and Commerce

JALS Journal of Air Law and Space

\footnotetext{
* Bimal N. Patel, BSc, MA (International Relations), LLM (International Law), PhD candidate, Nijmegen University, the Netherlands. Staff member, Verification Division, Organisation for the Prohibition of Chemical Weapons, The Hague. The author gratefully acknowledges the assistance of Mr Abhishek Sharma, LLB student National Law University, Jodhpur (India), intern at Gujarat National Law University, Gujarat (India).
}

Asian Yearbook of International Law, Volume 11 (B.S. Chimni et al., eds.)

(C) 2006 Koninklijke Brill NV. Printed in The Netherlands, pp. 383-406. 
Penn State ILR Penn State International Law Review

Texas ILJ Texas International Law Journal

TJAIL The Japanese Annual of International Law

Yale JIL Yale Journal of International Law

Air and space

ABEYRATNE, RUWANTISSA, Space tourism: parallel synergies between air and space law, 53 Zeitschrift für Luft- und Weltraumrecht (2) 184-202

CAPLAN, HAROLD, War and terrorism insurance: how to promote long-term international stability and affordability, 29 Air Space Law (1) 3-28

CHENG, BIN, A new era in the Law of International Carriage by Air: from Warsaw (1929) to Montreal (1999), 53 ICLQ (4) $833-859$

CLARK, LORNE S., The 2001 Cape Town Convention on International Interests in Mobile Equipment and Aircraft Equipment Protocol: internationalizing assetbased financing principles for the acquisition of aircraft and engines, $69 J A L C$ (1) 3-19

COLLIER, ALAN H., The Foreign Sovereign Immunities Act and its impact on aviation litigation, 69 JALC (3) 519-544

CRANS, BEREND, How to make sure your aircraft lease agreement covers (almost) everything, 29 Air Space Law (1) 29-41

DEMPSEY, PAUL STEPHEN, Flights of Fancy and Fights of Fury: arbitration and adjudication of commercial and political disputes in international aviation, 32 Georgia Journal of International and Comparative Law (2) 231-305

DIEDERIKS-VERSCHOOR, I.H.Ph., Current Practice and Developments in Air Cargo: Comparison of the Warsaw Convention
1929 and the Montreal Convention 1999, 39 European Transport Law (6) 739-757

DIEDERIKS-VERSCHOOR, I.H.Ph., The benefits of the use of outer space for the developing countries, Reflections on Emerging International Law, National Law School of India University, 200-204

DYSART, JENNIFER, The Warsaw Convention does not adequately protect the health of passengers in air transport: critically assess this statement, 39 European Transport Law (1) 17-30

GÓMEZ, JAVIER GUISÁNDEZ, The Law of Air Warfare, Naorem Sanajaoba (ed.) A Manual of International Humanitarian Laws, Regency Publications, 106-123

GRUNER, BRANDON C., A New Hope for International Space Law: Incorporating Nineteenth Century First Possession Principles into the 1967 Space Treaty for the Colonization of Outer Space in the Twenty-First Century, 35 Seton Hall Law Review (1) 299-357

HERMIDA, JULIAN, Convergence of civil law and common law contracts in the space field, 34 Hong Kong Law Journal (2) $339-375$

HUSTON, JAMES W. and BILL O'CONNOR, Admiralty law and jurisdiction in air crash cases, 69 Journal of Air Law and Commerce (2) 299-317

JACKSON, KENT S. and LORI N. EDWARDS, The changing face of passenger air transportation: the blurry line between Part 121 and 135 operators, 
69 Journal of Air Law and Commerce (2) 319-346

LONG, JEFFERY C., The Warsaw Convection Liability Scheme: what it covers, attempts to waive it and why the waivers should not be enforced until the airlines are financially stable, 69 Journal of Air Law and Commerce (1) 65-100

MIRMINA, STEVEN A., The regulation of orbital debris through national measures, 29 Air Space Law (2) 137-146

SHAMS, HEBA, The World Bank and investment protection: a question of accountability, Norbert Horn, ed., Arbitrating Foreign Investment Disputes, Kluwer Law International, 111-142

SHUPE, J. DENNY and GREGORY W. BUHLER, Commercial aircraft transactions: liability of owners, lessors and finance parties, 29 Air Space Law (6) 397-414

TANNENWALD, NINA, Law versus power on the high frontier: the case for a rulebased regime for outer space, 29 Yale JIL (2) $363-422$

THACKERAY JR, RICHARD W., Struggling for air: the Kyoto Protocol, citizens' suits under the Clean Air Act, and the United States' options for addressing global climate change, 14 Indiana International and Comparative Law Review (3) $855-903$

TOMPKINS JR, GEORGE N., Confiscation of hand baggage is an accident and wilful misconduct: report from the USA, 29 Air Space Law (4-5) 315-316

\section{Arbitration}

ALEXANDROV, STANIMIR A., Breaches of contract and breaches of treaty: the jurisdiction of treaty-based arbitration tribunals to decide breach of contract claims in Sgs v. Pakistan and Sgs v. Philippines, 5 The Journal of World Investment and Trade (4) 555-577

CHAN, ANTHONY W.Y., PADRAIG WALSH and WYNNE MOK, Foreign investment in E-commerce in China, 25 Comparative Law Yearbook of International Business, 203-231

GAZZINI, ISABELLE FELLRATH, Cultural Property Disputes: The Role of Arbitration in Resolving Non-contractual Disputes, Transnational Publishers, 306p.

GOODMAN, CARL F., Japan's new Civil Procedure Code: has it fostered a rule of law dispute resolution mechanism? 29 Brooklyn JIL (2) 511-616

GREENWOOD, DESMOND GERARD, Is mistake dead in contract law? $34 \mathrm{HKLJ}$ (3) $495-513$

HU, LI, Enforcement of foreign arbitral awards and court intervention in the People's Republic of China, 20 Arbitration International (2) 167-178

JAYNES, GORDON, International arbitration in Pakistan: a Janusian perspective, 21 Journal of International Arbitration (1) 83-89

JINGZHOU, TAO, Arbitration Law and Practice in China, Kluwer Law International, 331p.

KWATRA, G.K., Arbitration and Alternative Dispute Resolution: How to Settle International Business Disputes: With Supplement on Indian Arbitration Law, ICA, 420p.

MANIRUZZAMAN, A.F.M., Adoption of the UNCITRAL Model Law on Arbitration lock, stock and barrel: no, thank you: the 
Bangladesh Case, 7 International Arbitration Law Review (2) 61-64

MING, KANG, Ad hoc Arbitration in China, 6 International Arbitration Law Review (6) $199-202$

MOSER, MICHAEL J. and TERESA Y.W. CHENG, Hong Kong Arbitration: A User's Guide, Kluwer Law International, $569 \mathrm{p}$.

NISHIKAWA, RIEKO, Arbitration law reform in Japan, 21 Journal of International Arbitration (3) 303-308

NORTON, JOSEPH J., An "environmental" approach to FDI and effective dispute resolution: the exhortations of the Monterrey consensus, Norbert Horn (ed.) Arbitrating Foreign Investment Disputes, Kluwer Law International, 89-109

NOTTAGE, LUKE, Japan's new arbitration law: domestication reinforcing internationalisation, 7 International Arbitration Law Review (2) 54-60

ODA, HIROSHI, Arbitration reform in Japan, 15 The ICC International Court of Arbitration Bulletin (1) 23-35

POSCH, WILLIBALD, Resolving business disputes through litigation or other alternatives: the effects of jurisdictional rules and recognition practice, 26 Houston Journal of International Law (2) 363-383

ROWE, HEATHER, E-commerce: jurisdiction over on-line contracts and noncontractual cross-border disputes, part 1 , 19 Butterworths Journal of International Banking and Financial Law (2) 51-55

RUBINS, NOAH, The enforcement and annulment of international arbitration awards in Indonesia, 20 The American University International Law Review (2) 359-401
SUZUKI, KATSUMASA, Future prospects of takeovers in Japan analyzed from the view of share-ownership structures and laws in comparison with the United States and the European Union, 42 Columbia Journal of Transnational Law (3) $777-827$

TADA, NOZOMI, Enforcement of foreign judgments in Japan regarding business activities, 46 TJAIL, 75-94

WÄLDE, THOMAS W., Investment arbitration under the Energy Charter Treaty: an overview of selected key issues based on recent litigation experience, Norbert Horn (ed.) Arbitrating Foreign Investment Disputes, Kluwer Law International, 193235

WEILER, TODD, Saving Oscar Chin: nondiscrimination in international investment law, Norbert Horn (ed.) Arbitrating Foreign Investment Disputes, Kluwer Law International, 159-192

\section{Arms control and disarmament}

BOOTHBY, DEREK, Disarmament: success and failures, Jean E. Krasno (ed.), The United Nations, Lynne Rienner, 193-223

BYERS, MICHAEL, Policing the high seas: the proliferation security initiative, 98 AJIL (3) 526-545

CAPIE, DAVID, Regional introduction: missing the target: the human cost of small-arms proliferation and misuse in Southeast Asia, Annelies Heijmans, Nicola Simmonds and Hans van de Veen (eds.), Searching for Peace in Asia Pacific, Rienner, 294-312

CASSANDRA, MICHAEL F., Constructing barriers to proliferation and the illicit trade in weapons, Yassin El-Ayouty (ed.) Perspectives on 9/11, Praeger, 197-211 
CLARY, CHRISTOPHER, A. Q. Khan and the limits of the non-proliferation regime, Disarmament Forum (4) 33-42

ELBARADEI, MOHAMED, Preserving the Non-Proliferation Treaty, Disarmament Forum (4) 3-7

FEIVESON, HAROLD A. and JACQUELINE W. SHIRE, Dilemmas of compliance with arms control and disarmament agreements, Edward C. Luck and Michael W. Doyle (eds.) International Law and Organization, Rowman and Littlefield, 205-245

FIDLER, DAVID P., International law and weapons of mass destruction: end of the arms control approach? 14 Duke Journal of Comparative and International Law (1) 39-88

FREY, BARBARA A., Small arms and light weapons: the tools used to violate human rights, Disarmament Forum (3) 37-46

FRIEMAN, WENDY, China, Arms Control, and Non-proliferation, RoutledgeCurzon, $228 \mathrm{p}$.

HILL, STEPHEN M., United Nations Disarmament in Intra-state Conflict, Palgrave Macmillan, 303p.

JOYNER, DANIEL H., The enhanced proliferation control initiative: national security necessity or unconstitutionally vague? 32 Georgia Journal of International and Comparative Law (1) 107 123

KUROSAWA, MITSURU, Nuclear nonproliferation regime and nuclear disarmament: implementation of the 2000 final document, 51 Osaka University Law Review (February) 1-19

LEHRMAN, THOMAS D., Enhancing the proliferation security initiative: the case for a decentralized non-proliferation architecture, 45 Virginia Journal of International Law (1) 223-276

LEWIS, PATRICIA and RAMESH THAKUR, Arms control, disarmament and the United Nations, Disarmament Forum (1) 17-28

LOGAN, DAVID and STUART CROFT, Seizing the "ripe" moment: building confidence and security in South Asia, Disarmament Forum (2) 21-30

MANI, V.S., Future strategies in the war against terrorism and proliferation of weapons of mass destruction: an Indian perception, 44 IJIL (2) 221-259

MARÍN-BOSCH, MIGUEL, Disarmament education: practicing what you preach, Disarmament Forum (1) 49-56

MOXLEYJR, CHARLES J., The sword in the mirror: the lawfulness of North Korea's use and threat of use of nuclear weapons based on the United States' legitimization of nuclear weapons, 27 Fordham ILJ (4) 1379-1489

O'FLAHERTY, MICHAEL, Human rights monitoring and armed conflict: challenges for the UN, Disarmament Forum (3) 47 57

OHE, J. ANTONIO, Are landmines still needed to defend South Korea?: a mine use case study, Richard A. Matthew, Bryan McDonald and Kenneth R. Rutherford (eds.) Landmines and Human Security, State University of New York Press, 225-235

OUDRAAT, CHANTAL DE JONGE, The United Nations and the campaign against terrorism, Disarmament Forum (1) 29-37

PETERSMANN, ERNST-ULRICH, Proliferation and fragmentation of dispute settle- 
ment in international trade: WTO dispute settlement procedures and alternative dispute resolution mechanisms, Julio Lacarte and Jaime Granados (eds.) Intergovernmental Trade Dispute Settlement, Cameron May, 417-483

RAJEN, GAURAV, Strategic stability in South Asia: the need for restraint in targeting technologies, Disarmament Forum (2) 41-49

ROY-CHAUDHURY, RAHUL, The United States' role and influence on the IndiaPakistan conflict, Disarmament Forum (2) 31-39

SIMPSON, JOHN, The nuclear non-proliferation regime: back to the future? Disarmament Forum (1), 5-16

TAN JR, CHET J., The proliferation of bilateral non-surrender agreements among non-ratifiers of the Rome Statute of the International Criminal Court, 19 The American University International Law Review (5) 1115-1180

WEISS, PETER and JOHN BURROUGHS, Weapons of mass destruction and human rights, Disarmament Forum (3) 25-35

YUAN, JING-DONG, China's pragmatic approach to non-proliferation policies in the post-Cold War Era, Suisheng Zhao (ed.) Chinese Foreign Policy, Sharpe, 151-176

ZAMAN, IFTEKHAR, Living with a nuclearized South Asia: rethinking disarmament and security, Disarmament Forum (2) $51-58$

\section{Conflicts and disputes}

ADAM, HERIBERT, KANYA ADAM and KOGILA MOODLEY, Conditions for peacemaking: Negotiating the Non-negotiable in South Africa and the Middle
East, Ulrich Schneckener and Stefan Wolff (eds.) Managing and Settling Ethnic Conflicts, Hurst, 220-247

ADENEY, KATHARINE, Between Federalism and Separatism: India and Pakistan, Ulrich Schneckener and Stefan Wolff (eds.) Managing and Settling Ethnic Conflicts, Hurst, 161-175

ANAND, R.P., Effectiveness of International Judicial Procedures in the Settlement of International Disputes, R.K. Dixit and C. Jayaraj (eds.) Dynamics of International Law in the New Millennium, Indian Society of International Law, 61-81

ANDERSON, KENNETH, Humanitarian inviolability in crisis: the meaning of impartiality and neutrality for UN and NGO agencies following the 2003-2004 Afghanistan and Iraq conflicts, 17 Harvard Human Rights Journal (spring) 4174

BATES, DONNA M., A consumer's dream or Pandora's box: is arbitration a viable option for cross-border consumer disputes? 27 Fordham International Law Journal (2) 823-898

BAVIERA, AILEEN, South China Sea: managing Territorial and Resource Disputes, Annelies Heijmans, Nicola Simmonds and Hans van de Veen (eds.) Searching for Peace in Asia Pacific, Rienner, 505523

BENVENISTI, EYAL, Water conflicts during the Occupation of Iraq, Future Implications of the Iraq Conflict, American Society of International Law, 148-160

BLACKSHAW, IAN, Settling Sports Disputes in Cyberspace, The International Sports Law Journal (1-2) 20-25

BOOTHBY, DEREK and GEORGE D'ANGELO, Building Capacity within 
the United Nations: Cooperation on the Prevention of Violent Conflicts, Albrecht Schnabel and David Carment (eds.) Conflict Prevention from Rhetoric to Reality, Lexington Books, 251-271

CAPLAN, RICHARD, International Intervention and its Aftermath: Kosovo and East Timor, Ulrich Schneckener and Stefan Wolff (eds.) Managing and Settling Ethnic Conflicts, Hurst, 206-219

CHADDA, MAYA, Between Consociationalism and Control: Sri Lanka, Ulrich Schneckener and Stefan Wolff (eds.) Managing and Settling Ethnic Conflicts, Hurst, 94-114

CHAMBERLAIN, KEVIN, War and Cultural Heritage: An Analysis of the 1954 Convention for the Protection of Cultural Property in the Event of Armed Conflicts and its Two Protocols, Institute of Art and Law, 333p.

CHUNG, CHIEN-PENG, Domestic Politics, International Bargaining and China's Territorial Disputes, RoutledgeCurzon, $222 \mathrm{p}$.

DIXIT, R.K., Saving Cultural Property Holocaust during Armed Conflicts, R.K. Dixit and C. Jayaraj (eds.) Dynamics of International Law in the New Millennium, Indian Society of International Law, 183196

FREASE, STEFANIE, Playing Hide and Seek with International Justice: what went wrong in Indonesia and East Timor, 10 ILSA Journal of International and Comparative Law (2) 283-292

GARCÍA-BOLÍVAR, OMAR E., Foreign Investment Disputes under ICSID: a Review of its Decisions on Jurisdiction, 5 The Journal of World Investment and Trade (1) 187-214
HTUN, NAY, Landmines Prolong Conflicts and Impede Socioeconomic Development, Richard A. Matthew, Bryan McDonald and Kenneth R. Rutherford (eds.) Landmines and Human Security, State University of New York Press 169-177

JACQUES, BERTRAND, Nationalism and Ethnic Conflict in Indonesia, Cambridge University Press, 278p.

JOHNSTON, ALASTAIR IAIN, China's Militarized Interstate Dispute Behaviour 1949-1993: a first cut at the data, Guoli $\mathrm{Lu}$ (ed.) Chinese Foreign Policy in Transition, Aldine de Gruyter, 259-293

KADAM, UMESH, Protection of Women in Times of Armed Conflicts and Work of the International Committee of the Red Cross, R.K. Dixit and C. Jayaraj (eds.) Dynamics of International Law in the New Millennium, Indian Society of International Law, 197-205

KELMAN, HERBERT C., National Identity and the Role of the "Other" in Existential Conflicts: the Israeli-Palestinian Case, John Bunzl (ed.) Islam, Judaism, and the Political Role of Religions in the Middle East, University Press of Florida, 61-74

KISS, ALEXANDRE-CHARLES, Environmental Disputes and the Permanent Court of Arbitration, 16 Hague Yearbook of International Law 41-46

KNOX, JOHN H., The judicial resolution of conflicts between trade and the environment, 28 The Harvard Environmental Law Review (1) 1-78

LACARTE, JULIO and JAIME GRANADOS, Settlement of Inter-governmental Trade Disputes: Multilateral and Regional Approaches, Julio Lacarte and Jaime Granados (ed.) Inter-governmental Trade Dispute Settlement, Cameron May 607620 
LIU, DEMING, When the Patent Dispute is under Way, the Arbitration will Play: Perspective on Arbitration of Patent Disputes, La revue libanaise de l'arbitrage arabe et international (30) 7-17

LYNCH, DOV, Engaging Eurasia's Separatist States: Unresolved Conflicts and de facto States, United States Institute of Peace Press 170p.

MACCONKEY, MATTHEW, Foreign Investment and Trade Disputes in China, 18 China Law and Practice (10) 19-20

PAULSSON, JAN and ZACHARY DOUGLAS, Indirect expropriation in investment treaty arbitrations, Arbitrating Foreign Investment Disputes, Kluwer Law International 145-158

PINESCHI, LAURA, Non-Compliance Mechanisms and the Proposed Center for the Prevention and Management of Environmental Disputes, 20 Anuario de derecho internacional 241-278

PLATTNER, DENISE, The penal repression of violations of international humanitarian law applicable in non-international armed conflicts, Naorem Sanajaoba (ed.) A Manual of International Humanitarian Laws, Regency Publications 397-409

PRÉFONTAINE, DANIEL C., Under international law is there a category of prisoner in armed conflicts known as an "unlawful or unprivileged or enemy combatant"? The Measure of International Law, Kluwer Law International 386-395

ROPERS, NORBERT, From resolution to transformation: assessing the role and impact of dialogue projects, Andreas Wilmer (ed.) Facing Ethnic Conflicts, Rowman and Littlefield 174-188

RÖSEL, JAKOB, Democracy and ethnic conflicts: the politics of ethnicity and conflict resolution in South Asia, MarieClaire Foblets and Trutz von Trotha (eds.) Healing the Wounds, Hart 203-220

ROY-CHAUDHURY, RAHUL, The United States' role and influence on the IndiaPakistan conflict, Disarmament Forum (2) 31-39

SALACUSE, JESWALD W., Toward a Global Treaty on Foreign Investment: The Search for a Grand Bargain, Norbert Horn, Arbitrating Foreign Investment Disputes, Kluwer Law International 51-88

SCHINDLER, DIETRICH and JIRÍ TOMAN, The Laws of Armed Conflicts: A Collection of Conventions, Resolutions, and Other Documents, Nijhoff 1493p.

SCHNECKENER, ULRICH, Managing and Settling Ethnic Conflicts: Perspectives on Successes and Failures in Europe, Africa and Asia, Hurst 291p

SCHWABACH, AARON, Ecocide and genocide in Iraq: international law, the Marsh Arabs, and environmental damage in noninternational conflicts, 15 Colorado Journal of International Environmental Policy (1) 1-28

SISK, TIMOTHY D., Peacemaking in Civil Wars: Obstacles, Options and Opportunities, Ulrich Schneckener Managing and Settling Ethnic Conflicts: Perspectives on Successes and Failures in Europe, Africa and Asia, Hurst 248-270

SU, STEVEN WEI, The Tiaoyu Islands and their Possible Effect on the Maritime Boundary Delimitation between China and Japan, 3 Chinese Journal of International Law (2) 385-420

VISWANATHAN, T.K., Overview of Jurisdictional Conflicts in Cyberspace, R.K. Dixit and C. Jayaraj (eds.) Dynamics of International Law in the New Millennium, 
Indian Society of International Law 393407

\section{Criminal law, humanitarian law and terrorism}

AKANDE, DAPO, International Law Immunities and the International Criminal Court, 98 AJIL (3) 407-433

AKSAR, YUSUF, Implementing International Humanitarian Law: From the Ad hoc Tribunals to a Permanent International Criminal Court, Routledge 314p.

ANDERSON, KENNETH, Humanitarian inviolability in crisis: the meaning of impartiality and neutrality for UN and NGO agencies following the 2003-2004 Afghanistan and Iraq conflicts, 17 Harvard Human Rights Journal (spring) 4174

BASSIOUNI, CHERIF, The "Indirect Enforcement System": Modalities of International Cooperation in Penal Matters, International Criminal Law, Erès 411-463

BEJESKY, ROBERT, Falun Gong and reeducation through labor: traditional rehabilitation for the "misdirected" to protect societal stability within China's evolving Criminal Justice System, 17 Journal of Asian Law (2) 147-189

BENZING, MARKUS, The complementarity regime of the International Criminal Court: international criminal justice between state sovereignty and the fight against impunity, 7 Max Planck Yearbook of UN Law 591-632

BRUBACHER, MATTHEW R., Prosecutorial discretion within the International Criminal Court, 2 Journal of International Criminal Justice (1) 71-95

BURGESS, PATRICK, Justice and Reconciliation in East Timor: the Relation- ship Between the Commission for Reception, Truth and Reconciliation and the Courts, 15 Criminal Law Forum (1-2) 135-158

BURGESS, PATRICK, Justice and Reconciliation in East Timor: the Relationship Between the Commission for Reception, Truth and Reconciliation and the Courts, 15 Criminal Law Forum (1-2) 135-158

CEDARBAUM, JONATHAN G., Restrictions on U.S. attorneys practicing before international criminal tribunals, 98 AJIL (1) 141-149

CHESTERMAN, SIMON, Humanitarian intervention and Afghanistan, Jennifer M. Welsh (ed.) Humanitarian Intervention and International Relations, Oxford University Press, 163-175

COSTY, ALEXANDER, The dilemma of humanitarianism in the post-Taliban transition, Antonio Donini, Norah Niland and Karin Wermster (eds.) Nation-building Unraveled?, Kumarian Press, 143-165

DEMPSEY, GARY T., Reasonable Doubt: the Case against the Proposed International Criminal Court, William Driscoll, Joseph Zompetti and Suzette Zompetti (eds.) The International Criminal Court, International Debate Education Association 48-73

DÖRMANN, KNUT, War crimes under the Rome Statute of the International Criminal Court, with a special focus on the negotiations on the elements of crimes, 7 Max Planck Yearbook of UN Law 341407

DRISCOLL, WILLIAM, The International Criminal Court: Global Politics and the Quest for Justice, International Debate Education Association 285p. 
DROEGE, CORDULA, Criminal Justice Reform in India: ICJ Position Paper: Review of the Recommendations made by the Justice Malimath Committee from an International Human Rights Perspective, 2004 Yearbook of the International Commission of Jurists 147-189

ETCHESON, CRAIG, The Politics of Genocide Justice in Cambodia, Cesare P.R. Romano, André Nollkaemper, and Jann K. Kleffner (eds.) Internationalized Criminal Courts and Tribunals, Oxford University Press, 181-205

FANTAYE, DAWIT KIROS, Fighting corruption and embezzlement in Third World countries, 68 Journal of Criminal Law (2) 170-176

GAETA, PAOLO, Is the Practice of "SelfReferrals" a Sound Start for the ICC? 2 Journal of International Criminal Justice (4) 949-952

GHODSI, EBRAHIM, Murder in the criminal law of Iran and Islam, 68 Journal of Criminal Law (2) 160-169

HALL, TRAVIS, Address: Post-war criminal justice in Iraq, 33 Georgia Journal of International and Comparative Law (1) 157-169

HUNT, DAVID, The International Criminal Court: high hopes, "creative ambiguity" and an unfortunate mistrust in international judges, 2 Journal of International Criminal Justice (1) 56-70

ISLAM, SUHAIL and SYED HASSAN, The Wretched of the Nations: the West's Role in Human Rights Violations in the Bangladesh War of Independence, Adam Jones (ed.) Genocide, War Crimes and the West, Zed Books, 201-213

JESCHECK, HANS-HEINREICH, The general principles of international criminal law set out in Nuremberg, as mirrored in the ICC Statute, 2 Journal of International Criminal Justice (1) 38-55

KALSHOVEN, FRITS, From international humanitarian Law to international criminal Law, 3 Chinese Journal of International Law (1) 151-161

KAROUNTZOS, KONSTANTINOS, Universality principle, an orientation for international criminal law, 5 Griffin's View on International and Comparative Law (1) 128-138

KISSINGER, HENRY, The Pitfalls of Universal Jurisdiction, William Driscoll, Joseph Zompetti and Suzette Zompetti (eds.) The International Criminal Court, International Debate Education Association 93-101

KNOOPS, GERARDUS GODEFRIDUS JOHANNES, The Prosecution and Defense of Peacekeepers under International Criminal Law, Transnational Publishers 368p.

KRESS, CLAUS, "Self-Referrals" and "Waivers of Complementarity": some Considerations in Law and Policy, 2 Journal of International Criminal Justice (4) $944-948$

LAHTI, RAIMO, Towards harmonization of the general principles of international criminal law, International Criminal Law, Erès 345-351

LEWIS, BRIAN C., Prevention of computer crime amidst international anarchy, 41 The American Criminal Law Review (3) 1353-1372

LOG, SURE, The Practical Applications of $\mathrm{Ne}$ Bis in Idem in International Criminal Law, 2 International Crime and Punishment, University Press of America 169204 
MAXTED, JULIA, The International Criminal Court and the Prohibition of the Use of Children in Armed Conflict, Ramesh Thakur and Peter Malcontent (eds.) From Sovereign Impunity to International Accountability, United Nations University Press 253-263

MÉGRET, FRÉDÉRIC, Three dangers for the International Criminal Court: a critical look at a consensual project, Gerry Simpson (ed.) 2 War Crimes Law, Ashgate/Dartmouth 425-479

MISAWA, MITSURU, Director's Civil and Criminal Liabilities for Bad Debts at Japanese Banks, 18 Temple International and Comparative Law Journal (2) 311342

NATHAN, ELI, Explanation of Israel's Vote on the Adoption of the Statute of the International Criminal Court: United Nations Diplomatic Conference of Plenipotentiaries on the Establishment of an International Criminal Court: 9th Plenary Meeting: 17 July 1998: Statement, The International Criminal Court, International Debate Education Association 46-48

NESHEIWAT, FERRIS K., Honor Crimes in Jordan: their treatment under Islamic and Jordanian criminal laws, 23 Penn State International Law Review (2) 251281

ODORA, ALEX OBOTE, Criminal Responsibility of Journalists under International Criminal Law: the ICTR Experience, 73 NJIL (3) 307-323

OOSTERVELD, VALERIE, Sexual Slavery and the International Criminal Court: Advancing International Law, 25 Michigan Journal of International Law (3) 605-651
OWADA, HISASHI, The Creation of the International Criminal Court: a Critical Analysis, R.K. Dixit and C. Jayaraj (eds.) Dynamics of International Law in the New Millennium, Indian Society of International Law 82-112

ROY, DENNY, China and the War on Terrorism, Guoli Liu (ed.) Chinese Foreign Policy in Transition, Hawthorne New York, 323-334

SAROOSHI, DAN, Prosecutorial Policy and the ICC: Prosecutor's Proprio Motu Action or Self-Denial? 2 Journal of International Criminal Justice (4) 940-943

SAROOSHI, DAN, The peace and justice paradox: the International Criminal Court and the UN Security Council, The Permanent International Criminal Court, 95120

SASSÒLI, MARCO, The status of persons held in Guantánamo under international humanitarian law, 2 Journal of International Criminal Justice (1) 96-106

SCHABAS, WILLIAM A., United States Hostility to the International Criminal Court: it's all about the Security Council, 15 EJIL (4) 701-720

SCHEFFER, DAVID J., How to turn the tide using the Rome Statute's temporal jurisdiction, 2 Journal of International Criminal Justice (1) 26-34

SEIBERT-FOHR, ANJA, The relevance of the Rome Statute of the International Criminal Court for amnesties and truth commissions, 7 Max Planck Yearbook of UN Law, 553-590

SHAHABUDDEEN, MOHAMED, Does the principle of legality stand in the way of progressive development of law? 2 Journal of International Criminal Justice (4) 1007-1017 
SWART, BERT, International criminal courts and the admissibility of evidence, Ramesh Thakur and Peter Malcontent (eds.) From Sovereign Impunity to International Accountability, United Nations University Press, 135-153

TAN JR, CHET J., The proliferation of bilateral non-surrender agreements among non-ratifiers of the Rome Statute of the International Criminal Court, 19 The American University International Law Review (5) 1115-1180

TELLENBACH, SILVIA, Fair trial guarantees in criminal proceedings under Islamic, Afghan Constitutional and International Law, 64 Zeitschrift für ausländisches öffentliches Recht und Völkerrecht (ZaöRV) (4) 929-941

WALD, PATRICIA M., Is the United States' opposition to the ICC intractable? 2 Journal of International Criminal Justice (1) 19-25

WALKER, CLIVE, Terrorism and criminal justice: past, present and future, 2004 Criminal Law Review (May) 311-327

WEIGEND, THOMAS, The harmonization of general principles of criminal law: the statutes and jurisprudence of the ICTY, ICTR, and the ICC: an Overview, International Criminal Law, Erès, 319-335

\section{Economic relations, trade and Inter- national Finance}

ARAKI, ICHIRO, Beyond aggressive legalism: Japan and the GATT/WTO dispute, Mitsuo Matsushita and Dukgeun Ahn (eds.) WTO and East Asia, Cameron May, 149-175

ASHIMA GOYAL, Foreign investment in India: riding the wave, H.S. Kehal (ed.) Foreign Investment in Developing Countries, Palgrave Macmillan, 92-111
BALDIA, SONIA, Exhaustion and parallel imports in India, Christopher Heath (ed.) Parallel Imports in Asia, Kluwer Law International, 163-175

BENIN, CLAUDIO DE and SUSAN LAVENDER, Trading Places: CEPA and the new procedures on foreign-invested commercial enterprises, 18 China Law and Practice (5) 25-29

BHATTASALI, DEEPAK and SHANTONG LI, China and the WTO: Accession, Policy Reform, and Poverty Reduction Strategies, World Bank, 334p.

BHATTASALI, DEEPAK, Accelerating financial market restructuring in China, Deepak Bhattasali, Shantong Li, and Will Martin (eds.) China and the WTO, World Bank, 181-190

BRONCKERS, MARCO, The Special Safeguards Clause in WTO trade relations with China: (how) will it work? Mitsuo Matsushita and Dukgeun Ahn (eds.) WTO and East Asia, Cameron May, 39-50

CHAN, JEANETTE $K$. and AURIA STYLES, China Implements WTO Commitments on Rules of Origin, 18 China Law and Practice (10) 21-23

CHONG, JOHN, Exhaustion and parallel imports in Malaysia, Parallel Imports in Asia, Kluwer Law International, 123-135

COHEN, EVAN, MARY MATSON and PAUL CHU, Trust law provides key to China securitization, International Financial Law Review (June) 30-32

CROSS, ADAM R. and HUI TAN, The impact of China's WTO accession on Southeast Asian foreign direct investment: trends and prospects, Nick J. Freeman and Frank L. Bartels (eds.) The Future of Foreign Investment in Southeast Asia, 125-154 
DELES, PAOLA, Philippines participation in WTO dispute settlement, 78 Philippine Law Journal (3) 560-579

DELISLE, JACQUES and KEVIN P. LANE, Hong Kong's endgame and the rule of law (II): the battle over "the People" and the business community in the transition to Chinese rule, 25 University of Pennsylvania Journal of International Economic Law (4) 1525-1746

DENTERS, ERIK, The Bop-restrictions Case of US v. India: how the IMF may affect decision-making in the WTO, Reflections on Emerging International Law, National Law School of India University, 119-126

DING, CHANGYE, The new legal regime of foreign acquisitions in China, 25 The Company Lawyer (8) 252-255

EASTWOOD, JOHN, Taiwan and Mainland China: problems and prospects in crossborder IP issues, 18 China Law and Practice (2) 21-23

EGASHIRA, KENJIRO, The duties of directors of Japan's publicly held corporations, with an emphasis on supervisory issues, 9 Zeitschrift für japanisches Recht (17) 17-27

EICHELBERGER, JON and ANNABEL ALLEN, A legal perspective: the impact of WTO on foreign investment in China's Internet/E-commerce sector, Tung CheeChen (et al.) China WTO, 87-97

FIDER, ALEX FERDINAND S., Exhaustion and parallel imports in the Philippines, Christopher Heath (ed.) Parallel Imports in Asia, Kluwer Law International, 113121

GAO, FUPING, The E-Commerce legal environment in China: status quo and issues, 18 Temple International and Comparative Law Journal (1) 51-75
GUPTA, RISHI, TRIPS Compliance: dealing with the consequences of drug patents in India, 26 Houston Journal of International Law (3) 599-648

HAMADA, KOICHI, China's entry into the WTO and its impact on the global economic system, Mike Moore (ed.) Doha and Beyond / World Trade Organization, Cambridge University Press, 26-45

HARPAZ, GUY, Enhanced relations between the European Union and the State of Israel under the European Neighbourhood Policy: some legal and economic implications, 31 Legal Issues of Economic Integration (4) 257-274

HEATH, CHRISTOPHER, Exhaustion and Parallel Imports in Japan, Christopher Heath (ed.) Parallel Imports in Asia, Kluwer Law International, 51-71

HEYE, WILLIAM, Forum Selection for International Dispute Resolution in China: Chinese Courts vs. CIETAC, 27 Hastings International and Comparative Law Review (3) 535-554

HIRONAKA, AKIHIRO, Jurisdictional theory "Made in Japan": Convergence of U.S. and Continental European approaches, 37 Vanderbilt Journal of Transnational Law (5) 1317-1351

HONG, XUE, Online dispute resolution for E-Commerce in China: present practices and future developments, 34 Hong Kong Law Journal (2) 377-399

HOOGMARTENS, JAN, EC Trade Law Following China's Accession to the WTO, Kluwer Law International, 216p.

HORIKOSHI, HIDEO, Japan's new corporate reorganization law, 38 The International Lawyer (3) 855-865 
HOWSE, ROBERT, Back to court after Shrimp-Turtle: India's challenge to labor and environmental linkages in the EC generalized system of preferences, Eyal Benvenisti and Moshe Hirsch (eds.) The Impact of International Law on International Cooperation, Cambridge University Press, 261-298

HUAQAN, ZENG, Promoting a new bilateral legal framework for China-EU economic relations, 3 CJIL (1) 189-225

HUNG, VERON MEI-YING, China's WTO commitment on independent judicial review: impact on legal and political reform, 52 American Journal of Comparative Law (1) 77-132

JOHN TOYE and RICHARD TOYE, The UN and Global Political Economy: Trade, Finance, and Development, Indiana University Press 393p.

KAGAMI, MITSUHIRO, Effects of the FTAA on Japan, Paulo Vizentini and Marianne Wiesebron (eds.) Free Trade for the Americas? Zed Books 188-196

KANDA, HIDEKI, Legal issues relating to indirectly held investment securities in Japan, 46 TJAIL 46-56

KILLION, M. ULRIC, Post-WTO China and independent judicial review, 26 Houston Journal of International Law (3) 507-559

KILLION, M. ULRIC, Quest for legal safeguards for foreign exporters under China's anti-dumping regime, 29 North Carolina Journal of International Law and Commercial Regulation (3) 417-456

KIM, JOONGI, The challenges of attracting foreign investment into North Korea: the legal regimes of Sinuiju and Gaeseong, 27 Fordham International Law Journal (4) $1306-1321$
KONG, QINGJIANG, China's WTO Accession and the ASEAN-China Free Trade Area: the Perspective of a Chinese Lawyer, 7 Journal of International Economic Law (4) 839-861

LANGHAMMER, ROLF J., Revealed comparative advantages in the services trade of the United States, the European Union and Japan, 5 The Journal of World Investment and Trade (6) 887-896

LAYMAN, JEFFREY, IPR protection after WTO: copyright law and enforcement under the TRIPs agreement, Tung CheeChen (et al.): China WTO, 129-139

LEE, GILLIAN, Franchising in Singapore and Malaysia, 2 International Journal of Franchising Law (4) 34-36

LEE, MICHELE, Franchising in China: legal challenges when first entering the Chinese market, 19 The American University International Law Review (4) 9491007

LI, MEIXIAN, China's compliance with WTO requirements will improve the efficiency and effective implementation of environmental laws in China, 18 Temple International and Comparative Law Journal (1) 155-174

LIANG, LIU, Development of an independent director system in China, 5 Griffin's View on International and Comparative Law (2) 92-102

LIE, VINCENT ARIESTA, Establishing a company with foreign capital in Indonesia: a comparison with Dutch Law on formally foreign companies and the Inspire Art Case, 5 Griffin's View on International and Comparative Law (2) 51-66

LOPPACHER, LAURA J. and WILLIAM A. KERR, Integrating China's biotechnology 
industry into global knowledge creation: intellectual property protection is the key, 7 The Journal of World Intellectual Property (4) 549-562

LOW, CHEE KEONG, A framework for the delisting of Penny Stocks in Hong Kong, 30 North Carolina Journal of International Law and Commercial Regulation (1) $75-120$

MA, JING, Product-specific safeguard in China's WTO Accession Agreement: an analysis of its terms and its initial application in Section 421 investigations, 22 Boston University International Law Journal (1) 189-217

MAARIF, SYAMSUL, Competition law in Indonesia: framework and technical assistance, Tzong-Leh Hwang and Chiyuan Chen (eds.) The Future Development of Competition Framework, Kluwer Law International, 269-274

MACCONKEY, MATTHEW, Foreign Investment and Trade Disputes in China, 18 China Law and Practice (10) 19-20

MACKEY, TIM, The WTO dispute settlement process and the de-regulation of Japan's retail sector, 10 Auckland University Law Review, 36-60

MANNIX, ROB, How Malaysia plans to dominate Islamic markets, International Financial Law Review (September) 60-63

MEHRA, SALIL K., Software as crime: Japan, the United States, and contributory copyright infringement, 79 Tulane Law Review (2) 265-310

MINION, HANNA, Doing Business with Japan: Investment Regulations and Commercial Strategies, Asia Law and Practice $121 \mathrm{p}$.
MODWEL, SUMAN, The WTO and Agriculture: why is India so furious? 5 The Journal of World Investment and Trade (2) 289-319

MOON, CHUNG-IN, South Korea and international compliance behavior: the WTO and IMF in comparative perspective, Edward C. Luck and Michael W. Doyle (eds.) International Law and Organization, Rowman and Littlefield, 61-92

PAILWAR, VEENA KESHAV, Foreign direct investment, resource availability and efficiency in India, H.S. Kehal (ed.) Foreign Investment in Developing Countries, Palgrave Macmillan, 112-133

PAREKH, SANDEEP, Prevention of insider trading and corporate good governance in India, 32 International Business Lawyer (3) 132-140

PING-LI, TANG, Risk faced by shareholders and precautionary measures in case of takeovers in China, 5 Griffin's View on International and Comparative Law (2) $67-76$

PLATT, DAVID, Project finance for the People's Republic of China: WTO and other developments, Tung Chee-Chen (et al.) China WTO, 67-73

PRASAD, RAKESH, On the road to Madrid: what will it take for India to join the Madrid system for the international registration of trademarks? 32 International Business Lawyer (5) 209-215

QIN, JULIA YA, WTO Regulation of subsidies to state-owned enterprises (SOE's): a critical appraisal of the China accession protocol,: 7 Journal of International Economic Law (4) 863-919

RAJESH, RAJ, Indo-Caribbean trade and economic cooperation, India Quarterly (November) 173-217 
RAMASAMY, BALA and MATTHEW YEUNG, The European Union's foreign direct investment into Indonesia: determinants and threats, H.S. Kehal (ed.) Foreign Investment in Developing Countries, Palgrave Macmillan, 134-153

SHEN SIBAO, WTO and China's legal system, Mitsuo Matsushita and Dukgeun Ahn (eds.) WTO and East Asia, Cameron May, 267-290

SILALAHI, PANDE RADJA, Current development of competition law and policy in Indonesia, Tzong-Leh Hwang and Chiyuan Chen (eds.) The Future Development of Competition Framework, Kluwer Law International, 49-57

SRIVASTAVA, SADHANA and RAMKISHEN S. RAJAN, What does the economic rise of China imply for ASEAN and India?: focus on trade and investment flows, H.S. Kehal (ed.): Foreign Investment in Developing Countries, Palgrave Macmillan, 171-204

STENDER, NEAL, MATTHEW MACCONKEY and BI XING, China's Foreign Trade Law revised for WTO Era, 18 CLP (4) $14-16$

SUAMI, TAKAO, WTO and local government in Japan: examples of the Agreement on Government Procurement, 46 TJAIL 57-74

SUBRAHMANYAN, ARJUN, Looking ahead: issues in China's telecommunications law, 18 China Law and Practice (2) 33-36

SUN, LIU, Lessons from China's WTO accession negotiations: a look at likely implementation problems ahead, Nico Schrijver and Friedl Weiss (eds.) International Law and Sustainable Development, Nijhoff 185-216
SWEE, LEE KAM, Reconciling competition policy with development policies: the case of Malaysia, Tzong-Leh Hwang and Chiyuan Chen (eds.) The Future Development of Competition Framework, Kluwer Law International 261-268

TAHA, SAYED M., Pakistan-India trade policy under WTO, 57 Pakistan Horizon (3) $105-119$

TATSUTO, MISAO, Fundamental issues of corporate governance in Japan, 9 Zeitschrift für japanisches Recht (17) 5-16

THILAK, JITHEESH, Regulating M\&As: an insight into competition laws in India, 32 International Business Lawyer (4) 161165

TUNG, C.C., Positioning Hong Kong after China's WTO entry, Tung Chee-Chen (et al.) China WTO, 31-34

VASUDEVA, P.K., Foreign investment, foreign trade and related issues: a case study for India and China, H.S. Kehal (ed.) Foreign Investment in Developing Countries, Palgrave Macmillan, 205-222

WEINSTEIN, VERONICA and DENNIS FERNANDEZ, Recent developments in China's intellectual property laws, 3 CJIL (1) 227-239

WEN, CARSON and LEORA BLUMBERG, WTO dispute settlement mechanism and the emerging jurisprudence, Tung CheeChen (et al.) China WTO, 141-148

WONG, CINDY WAI CHI, Parallel importation of trademarked goods in Hong Kong and China, 34 Hong Kong Law Journal (1) $151-186$

XIANG, YU, The regime of exhaustion and parallel imports in China: a study based on the newly amended Chinese laws and 
related cases, 26 European Intellectual Property Review (3) 105-112

XU, SHIRLEY and RANDALL PEERENBOOM, Grand opening: new rules for foreign investment break open China's commercial sector: MOFCOM's new rules provide foreign investors greatly expanded opportunities in wholesale and retail, $18 C L P$ (4) 12-13

YAN, WENDY, The Electronic Signatures Law: China's first national E-commerce legislation, 18 CLP (9) 35-40

YING, ZHENG, Minority shareholder protection in China: present approaches and further improvements, 5 Griffin's View on International and Comparative Law (2) $77-91$

YOSHII, TAKESHI, Japan's corporate auditor system, 9 Zeitschrift für japanisches Recht (17) 39-47

YU, XIANG, Exhaustion and parallel imports in China, Christopher Heath (ed.) Parallel Imports in Asia, Kluwer Law International, 25-38

ZERUI, YANG, China's reaction and strategy towards the creation of the FTAA, Paulo Vizentini and Marianne Wiesebron (eds.) Free Trade for the Americas? Zed Books, 178-187

ZHANG, KEVIN HONGLIN, Maximizing benefits from foreign direct investment and minimizing its costs: what can we learn from China? H.S. Kehal (ed.) Foreign Investment in Developing Countries, Palgrave Macmillan, 78-91

Environment, natural resources and sustainable development

ANDREWS-SPEED, C.P., Energy Policy and Regulation in the People's Republic of China, Kluwer Law International, 19
International Energy and Resources Law and Policy Series, 367-384

KEYUAN, ZOU, Transnational cooperation for managing the control of environmental disputes in East Asia, 16 Journal of Environmental Law (3) 341-360

HAAN, MAX, An analysis of the regulatory framework for common effluent plants in Hyderabad, South India, 15 The Journal of Water Law (3-4) 172-176

HSU, BERRY FONG CHUNG, Constitutional protection of a sustainable environment in the Hong Kong special administrative region, 16 Journal of Environmental Law (2) 193-214

JUNID, ABDUL KADER AL, Towards good water governance in Malaysia: establishing an enabling legal environment, 2004 The Malayan Law Journal (1) CIV-CXX

KELLY, WYNNE P., Citizens cannot stand for it anymore: how the United States' environmental actions in Afghanistan and Iraq go unchecked by individuals and non-governmental organizations, 28 Fordham International Law Journal (1) 193231

KHALID, ABU RAIHAN M., The Interlinking of Rivers Project in India and International Water Law: an overview, 3 CJIL (2) $553-570$

MADIEHA, IDA and ABDUL GHANI AZMI, The protection of plant varieties in Malaysia, 6 The Journal of World Intellectual Property (6) 877-890

NAKATANI, KAZUHIRO, Energy security and Japan: the role of international law, domestic law and diplomacy, Barry Barton (ed.) Energy Security, Oxford University Press, 413-427 
RAZZAQUE, JONA, Public Interest Environmental Litigation in India, Pakistan and Bangladesh, Kluwer Law International, 502p

SATRIA, ARIF and YOSHIAKI MATSUDA, Decentralization of fisheries management in Indonesia, 28 Maritime Policy (5) 437450

TAKAHASHI, MITSUHIKO A., Cats v. birds in Japan: how to reconcile wildlife conservation and animal protection, 17 The Georgetown International Environmental Law Review (1) 135-159

WANG, SHIZHOU, Environmental crime and environmental criminal law in the People's Republic of China, 12 European Journal of Crime (2) 150-165

WANG, XUEMAN, Challenges and dilemmas in developing China's National Biosafety Framework, 38 Journal of World Trade (5) 899-913

XIWEN, CHEN, China's agricultural development and policy readjustment after its WTO accession, Deepak Bhattasali, Shantong Li and Will Martin (eds.) China and the WTO, World Bank, 69-79

ZHANG, JIEBIN, Water law and unified water administration in China: the Tarim River Basin under the HELP Program, 15 The Journal of Water Law (3-4) 127-130

ZHAO, YUHONG, Environmental dispute resolution in China, 16 Journal of Environmental Law (2) 157-192

ZUSMAN, ERIC, Environmental legislation in China: reacting to environmental problems, 3 Chinese Law and Government (3) $1-100$

\section{General}

Administration of association between law firms of the Hong Kong and Macao Special Administrative Regions and mainland law firms procedures, 18 CLP (1) $56-62$

BOSE, AMITABHA, Do all roads lead to Islamic radicalism?: a comparison of Islamic laws in India and Nigeria, 32 Georgia Journal of International and Comparative Law (3) 779-812

GINSBERG, PATRICIA, An ethical dilemma of American attorneys in China: the conflict between the duty of confidentiality to clients and the requirement of disclosure to the Chinese government, Mary C. Daly and Roger J. Goebel (eds.) Rights, Liability, and Ethics in International Legal Practice, Juris, 397-406

KAMIL, SULAEMAN, The protection of traditional knowledge in Indonesia, Sophia Twarog and Promila Kapoor (eds.) Protecting and Promoting Traditional Knowledge, United Nations, 193196

LI, YUWEN, Practising law in the People's Republic of China, Reflections on Emerging International Law, National Law School of India University, 205-212

NORTON, PATRICK M., The Foreign Corrupt Practices Act: a minefield for US companies in China, 18 CLP (9) 15-23

Individuals, groups of persons - human rights

AGARWAL, RANJAN K., The Barefoot Lawyers: prosecuting child labour in the Supreme Court of India, 21 Arizona JICL (2) 663-713 
BOURGON, JÉRÔME, Rights, freedoms, and customs in the making of Chinese Civil Law, 1900-1936, William C. Kirby (ed.) Realms of Freedom in Modern China, Stanford University Press, 84-112

CHANDER, VINEET, "It's (still) a boy ...": making the pre-natal diagnostic techniques act an effective weapon in India's struggle to stamp out female feticide, 36 The George Washington IL Review (2) 453-475

CHAN-TIBERGHIEN, JENNIFER, Gender and Human Rights Politics in Japan: Global Norms and Domestic Networks, Stanford University Press, 220p.

CHEN, CHIH-JOU JAY, Transforming rural China: how local institutions shape property rights in China, 21 RoutledgeCurzon Studies on China in Transition, RoutledgeCurzon, 188-207

CHO, BYUNG-SUN, The death penalty in South Korea and Japan: "Asian values" and the debate about capital punishment? Peter Hodgkinson and William A. Schabas (eds.) Capital Punishment, 253272

DAM, SHUBHANKAR, People's Union for Civil Liberties v Union of India: is Indian democracy dependent on a statute? Public Law (Winter) 704-711

DRUMBL, MARK A., Rights, culture, and crime: the role of rule of law for the women of Afghanistan, 42 Columbia Journal of Transnational Law (2) 349390

FIRMO-FONTAN, VICTORIA, Responses to sexual slavery: from the Balkans to Afghanistan, Christien van den Anker (ed.) The Political Economy of New Slavery, Palgrave Macmillan, 91-106
GLADNEY, DRU C., Dislocating China: Reflections on Muslims, Minorities, and other Subaltern Subjects, University of Chicago Press, 368-401

GOLDMAN, MERLE, Monitoring human rights in China, Debra Liang-Fenton (ed.) Implementing U.S. Human Rights Policy, 115-145

HENRARD, KRISTIN, Relating human rights, minority rights and self-determination to minority protection, Ulrich Schneckener and Stefan Wolff (eds.) Managing and Settling Ethnic Conflicts, Hurst, 40-56

HUSSAIN, FAQIR, Reforming the law of Zina (Adultery), Mohammad Yasin and Tariq Banuri (eds.): The Dispensation of Justice in Pakistan, Sustainable Development Policy Institute, 44-57

IIDA, KEISUKE, Human rights and sexual abuse: the impact of international human rights law on Japan, 26 Human Rights Quarterly (2) 428-453

JAHAN, ROUNAQ, Genocide in Bangladesh, Samuel Totten, William S. Parsons and Israel W. Charney (eds.) Century of Genocide: Critical Essays and Eyewitness Accounts, Routledge, 295-319

KAARTHIKEYAN, D.R., Human rights in India, Shale Horowitz and Albrecht Schnabel (eds.) Human Rights and Societies in Transition, United Nations University Press, 363-388

KHAN, ARSHI, Federalism and non-territorial minorities in India, G. Alan Tarr, Robert F. Williams and Josef Marko (eds.) Federalism, Subnational Constitutions, and Minority Rights, Praeger, 199212

KILliON, M. ULRIC, Post-WTO China: quest for human rights safeguards in 
sexual harassment against working women, 12 Tulane Journal of International and Comparative Law, 201-235

KOBAYASHI, YOSHIE, A Path Toward Gender Equality: State Feminism in Japan, Routledge 217p.

LEUNG, MAN-TO, Political development and democratic rights in Greater China, Shale Horowitz and Albrecht Schnabel (eds.) Human Rights and Societies in Transition, United Nations University Press, 339-362

MONSHIPOURI, MAHMOOD, Exploring the dynamics of human rights and reform: Iran, Pakistan, and Turkey, Shale Horowitz and Albrecht Schnabel (eds.) Human Rights and Societies in Transition, United Nations University Press, 218-241

RATNAM, C.S. VENKATA and ANIL VERMA, Hard law or soft law: India and international labour standards, John J. Kirton and Michael J. Trebilcock (eds.) Hard Choices, Soft Law, Ashgate, 153169

ROEHRIG, TERENCE, Human rights, the military, and the transition to democracy in Argentina and South Korea, Shale Horowitz and Albrecht Schnabel (eds.) Human Rights and Societies in Transition, United Nations University Press, 389-411

ROY, RAJA DEVASISH, Challenges for juridical pluralism and customary laws of indigenous peoples: the case of the Chittagong Hill Tracts, Bangladesh, 21 Arizona JICL (1) 113-182

SCHWARTZ, ABIGAIL, Sex trafficking in Cambodia, 17 Journal of Asian Law (2) $371-432$

SHIN, YOUNGTAE, Women and Politics in Japan and Korea, Mellen Press, 198p.
SKALLA, NICOLE M., China's one-child policy: illegal children and the family planning law, 29 Brooklyn JIL (3) 329363

WAHEED, MANAR, Domestic violence in Pakistan: the tension between intervention and sovereign autonomy in human rights law, 29 Brooklyn JIL (2) 937-975

WALIKHANNA, CHARU, Women Silent Victims in Armed Conflict: An Area Study of Jammu and Kashmir, India, Serials, $149 \mathrm{p}$.

YAKUSHIJI, KIMIO, Domestic implementation of human rights conventions and judicial remedies in Japan, 46 TJAIL, 145

YASUDA, YOSHIHIRO, The death penalty in Japan, Robert Badinter (et al.) The Death Penalty, Council of Europe Publishing, 215-231

\section{International courts and tribunals}

BENZING, MARKUS and MORTEN BERGSMO, Some tentative remarks on the relationship between internationalized criminal Jurisdictions and the International Criminal Court, Romano, Nollkaemper and Kleffner (eds.) Internationalized Criminal Courts and Tribunals, Oxford University Press, 407-426

COLITTI, MARIACARMEN, Geographical and jurisdictional reach of ICC: gaps in the international criminal justice system and a role for internationalized bodies, Romano, Nollkaemper and Kleffner (eds.) Internationalized Criminal Courts and Tribunals, Oxford University Press, 417426

CONDORELLI, LUIGI and THÉO BOUTRUCHE, Internationalized criminal courts and Tribunals: are they necessary? Romano, Nollkaemper and Kleffner (eds.) 
Internationalized Criminal Courts and Tribunals, Oxford University Press, 427436

GOVINDARAJ, V.C., Domestic courts and international human rights: recent developments in the U.S., U.K. and India, R.K. Dixit and C. Jayaraj (eds.) Dynamics of International Law in the New Millennium, Indian Society of International Law, 158182

GURUSWAMY, LAKSHMAN, Jurisdictional conflicts between the international tribunals: a framework for adjudication and implementation, David D. Caron and Harry N. Scheiber (eds.) Bringing New Law to Ocean Waters, Nijhoff, 297-347

LAHIRI, DILIP, Explanation of India's vote on the adoption of the Statute of the International Criminal Court: United Nations Diplomatic Conference of Plenipotentiaries on the Establishment of an International Criminal Court: $9^{\text {th }}$ Plenary Meeting: 17 July 1998: Statement, William Driscoll, Joseph Zompetti and Suzette Zompetti (eds.) The International Criminal Court, International Debate Education Association, 42-45

LINTON, SUZANNAH, Unraveling the first three Trials at Indonesia's Ad Hoc Court for Human Rights Violations in East Timor, 17 LJIL (2) 303-361

LUFTGLASS, SCOTT, Crossroads in Cambodia: the United Nation's responsibility to withdraw involvement from the establishment of a Cambodian tribunal to prosecute the Khmer Rouge, 90 Virginia Law Review (3) 893-964

LYONS, BETH S., Getting untrapped, struggling for truths: the Commission for Reception, Truth and Reconciliation (CAVR) in East Timor, Romano, Nollkaemper and Kleffner (eds.) Inter- nationalized Criminal Courts and Tribunals, Oxford University Press, 99-124

MEIJER, ERNESTINE E., The Extraordinary Chambers in the Courts of Cambodia for prosecuting crimes committed by the Khmer Rouge: jurisdiction, organization, and procedure of an internationalized national tribunal, Romano, Nollkaemper and Kleffner (eds.) Internationalized Criminal Courts and Tribunals, Oxford University Press, 207-232

PELLET, ALAIN, Strengthening the role of the International Court of Justice as the principal judicial organ of the United Nations, 3 The Law and Practice of International Courts and Tribunals: A Practioners' Journal 2, 159-180

PELLET, ALAIN, Internationalized courts: better than nothing, Romano, Nollkaemper and Kleffner (eds.) Internationalized Criminal Courts and Tribunals, Oxford University Press 437-444

ROMANO, CESARE P.R., ANDRÉ NOLLKAEMPER and JANN K. KLEFFNER, Internationalized criminal courts and tribunals: Sierra Leone, East Timor, Kosovo, and Cambodia, Cesare P.R. Romano, André Nollkaemper, and Jann K. Kleffner (eds.) International Courts and Tribunals Series, Oxford University Press, 445-462

\section{Legal Education}

GINSBURG, TOM, Transforming Legal Education in Japan and Korea, 22 Penn State ILR (3) 433-439

\section{National and international law}

ALI, SHAHEEN SARDAR and KAMRAN ARIF, Traditional/Alternative Dispute Resolution Mechanisms in Pakistan, Mohammad Yasin and Tariq Banuri (eds.) The Dispensation of Justice in 
Pakistan, Sustainable Development Policy Institute, 115-150

ASADA, MASAHIKO, Reservations and interpretative declarations made by Japan in signing or ratifying treaties (19902001), 46 TJAIL, 95-126

BURNS, PETER JOHN, The Leiden Legacy: Concepts of Law in Indonesia, KITLV Press, 307p.

CHAN, JOHANNES, Some thoughts on constitutional reform in Hong Kong, 34 Hong Kong Law Journal (1) 1-12

CLERMONT, KEVIN M., A global law of jurisdiction and judgments: views from the United States and Japan, 37 Cornell ILJ (1) 1-26

FUKUI, KOTA, Justice system reform in Japan: the connection between conflict management and realization of general rules of law, 51 Osaka University Law Review (February) 55-76

FUNG, DANIEL R., Constitutional Reform in China: the Case of Hong Kong, 39 Texas ILJ (3) 467-477

HSU, BERRY F.C., Judicial independence under the basic law, $34 H K L J$ (2) 279302

NANDA, VED P., International Law in Ancient Hindu India, Mark W. Janis and Carolyn Evans (eds.) Religion and International Law, Nijhoff, 51-62

NOTTAGE, LUKE, Product Safety and Liability Law in Japan: from Minamata to Mad Cows, Routledge Curzon, 308p.

TAKAGI, SHINJIRO, Cross-border insolvency in Japan, 32 International Business Lawyer (1) 15-17
TARUMOTO, HIDEKI, Multiculturalism in Japan: citizenship policy for immigrants, John Rex and Gurharpal Singh (eds.) Governance in Multicultural Societies, Ashgate, 214-226

WESLEY-SMITH, PETER, Judges and judicial power under the Hong Kong basic law, 34 HKLJ (1) 83-107

YOON, DAE-KYU, The constitution of North Korea: its changes and implications, 27 Fordham ILJ (4) 1289-1305

YOUNG, SIMON N.M., Restricting basic law rights in Hong Kong, $34 H K L J$ (1) 109-132

\section{Peace and security}

AHMED, SAMINA, Post-Taliban Afghanistan and South Asian Security, Ramesh Thakur and Oddny Wiggen (eds.) South Asia in the World, United Nations University Press, 357-372

WHITING, ALLEN S., Asean eyes China: the security dimension, Guoli Liu (ed.) Chinese Foreign Policy in Transition, Aldine de Gruyter, 233-256

\section{Peace-keeping, peace-making and peace- building}

NAMBIAR, SATISH, South Asian contributions to United Nations peacekeeping operations, with particular reference to India's participation, Ramesh Thakur and Oddny Wiggen (eds.) South Asia in the World, United Nations University Press, 104-114

ROOMY, SYED FATEMY AHMED, The United Nations and South Asia: Bangladesh's contribution to UN peacekeeping, Ramesh Thakur and Oddny Wiggen (eds.) South Asia in the World, United Nations University Press, 115-128 
SUTO, NOBUHIKO, Japan: accepting the challenges of conflict prevention and peacebuilding: Introduction,n Annelies Heijmans, Nicola Simmonds and Hans van de Veen (eds.) Searching for Peace in Asia Pacific, Rienner, 153-164

WANG, QINGXIN K. and MELISSA G. CURLEY, Poverty and non-traditional security: experiences of China's partnership with multilateral donor institutions on poverty alleviation, Ramesh Thakur and Edward Newman (eds.) Broadening Asia's Security Discourse and Agenda, United Nations University Press, 72-96

\section{States and groups of states}

BHASIN, LALIT, International succession: India, Louis Garb (ed.) International Succession, Kluwer Law International, 300-313

BOWEN, JOHN R., The search for new sources of legitimacy in Indonesia after Suharto, Marie-Claire Foblets and Trutz von Trotha (eds.) Healing the Wounds, Hart, 241-257

DONIN, ANTONIO, NORAH NILAND and KARIN WERMESTER, Nation-building Unraveled?: Aid, Peace and Justice in Afghanistan, Kumarian Press, 236p.

HIDAYAT, SYARIF and HANS ANTLÖV, Decentralization and regional autonomy in Indonesia, Philip Oxhorn, Joseph S. Tulchin and Andrew D. Selee (eds.) Decentralization, Democratic Governance, and Civil Society in Comparative Perspective, Woodrow Wilson Center Press, 266-291

JEN-KAI, LIU, PRC agreements with foreign countries, 33 China Aktuell (2) 202-208

KIM, HONG NACK, Japanese-North Korean relations after the 2002 Pyonguang Sum- mit, 28 Korea and World Affairs (2) 163197

KIRBY, WILLIAM C., Realms of Freedom in Modern China, Stanford University Press, 396p.

MACWHINNEY, EDWARD, The renewed vitality of the international law principles of peaceful coexistence in the post-Iraq invasion era: the 10th anniversary of the China/India Pancha Shila Agreements of 1954, 3 CJIL (2) 379-384

NEARY, IAN, Parliamentary democracy in Japan, 57 Parliamentary Affairs (3) 666681

PARTHASARATHY, G., India-Pakistan relations: ways forward, Ramesh Thakur and Oddny Wiggen (eds.) South Asia in the World, United Nations University Press, 429-440

PEOU, SORPONG, The UN's modest impact on Cambodia's democracy, Edward Newman and Roland Rich (eds.) The UN Role in Promoting Democracy, United Nations University Press, 258-281

PETERSEN, CAROLE J., Racial equality and the law: creating an effective statute and enforcement model for Hong Kong, 34 HKLJ (3) 459-480

SUBRAHMANYAN, ARJUN, Constitutionalism in China: changing dynamics in legal and political debates, 18 CLP (4) $17-23$

SUBRAHMANYAN, ARJUN, Growth and change: the diverse challenges facing Chinese law firms, 18 CLP (5) 17-24

WANG, RICHARD XIAOYUN, International succession: China, Louis Garb (ed.) International Succession, Kluwer Law International, 156-165 
ZHENG, YONGNIAN, Globalization and state transformation in China, Cambridge Asia-Pacific Studies, Cambridge University Press, 233-256

\section{United Nations and other international/ regional organizations and regional laws}

ARCHIBALD, JAMES E., Pledges of voluntary contributions to the United Nations by Member States: establishing and enforcing legal obligations, 36 George Washington International Law Review (2) 317-376

CORELL, HANS, A challenge to the United Nations and the world: developing the rule of law, 18 Temple International and Comparative Law Journal (2) 391-402

FASSBENDER, BARDO, All illusions shattered?: looking back on a decade of failed attempts to reform the UN Security Council, 7 Max Planck Yearbook of UN Law, 183-218

FRIEDRICH, ALEXANDER G. and GALE VALENCE E., Public-Private Partnership within the United Nations System: Now and Then, Bertelsmann, 147p.

JOB, BRIAN L., The UN, regional organizations, and regional conflict: is there a viable role for the UN? Richard M. Price and Mark W. Zacher, The United Nations and Global Security, 227-244

KOHONA, PALITHA T., The advancement of the international rule of law: the role of the United Nations, R. K. Dixit and C. Jayaraj (eds.) Dynamics of International Law in the New Millennium, Indian Society of International Law, 21-43
LAURENTI, JEFFREY, Financing the United Nations, Jean E. Krasno (ed.) The United Nations, Lynne Rienner, 271-309

LUFTGLASS, SCOTT, Crossroads in Cambodia: the United Nation's responsibility to withdraw involvement from the establishment of a Cambodian tribunal to prosecute the Khmer Rouge, 90 Virginia Law Review (3) 893-964

MANI, V. S., Six decades of the United Nations: an Indian perception, 44 IJIL (1) $1-73$

SUY, ERIK, Is the United Nations Security Council Still Relevant?: and was it ever? 12 Tulane Journal of International and Comparative Law, 7-25

THAKUR, RAMESH, Developing countries and the intervention-sovereignty debate, Richard M. Price and Mark W. Zacher, The United Nations and Global Security, United Nations University Press, 193-208

WEISS THOMAS G., FORSYTHE, DAVID P. and COATE, ROGER A., The United Nations and Changing World Politics, Westview Press, 392p.

ZACHER, MARK W., The conundrums of international power sharing: the politics of Security Council reform, Richard M. Price and Mark W. Zacher, The United Nations and Global Security, 211-226

ZWANENBURG, MARTEN COENRAAD, Accountability under International Humanitarian Law for United Nations and North Atlantic Treaty Organization Peace Support Operations, Leiden, E.M. Meijers Institute, 394p. 